\title{
Complement components and IgE in patients with asthma and aspirin idiosyncrasy
}

\author{
J. C. DELA NEY ${ }^{1}$ and A. B. $\mathrm{KA} \mathrm{Y}^{2}$ \\ Walton Hospital, Rice Lane, Liverpool', South-East Scotland Regional Blood Transfusion \\ Service, Royal Infirmary, Edinburgh ${ }^{2}$, and Department of Respiratory Diseases, \\ University of Edinburgh
}

\begin{abstract}
Delaney, J. C. and Kay, A. B. (1976). Thorax, 31, 425-427. Complement components and IgE in patients with asthma and aspirin idiosyncrasy. Levels of circulating IgE, total haemolytic complement, and components C4 and C3 were measured in 16 asthmatics with aspirin idiosyncrasy and in control subjects. IgE levels were mostly within normal limits. No differences were found between the complement profiles-in particular the $\mathrm{C} 4$ levels-in the two groups. As low levels of $\mathrm{C} 4$ have been found in patients with intrinsic asthma, these results would suggest a fundamental difference between asthmatics with aspirin idiosyncrasy and others with intrinsic asthma.
\end{abstract}

The development of increased airways obstruction soon after aspirin ingestion is a well recognized clinical entity (Samter and Beers, 1967). It is seen more commonly in females and typically it is associated with the presence of vasomotor rhinitis and nasal polyposis. The same effect may be produced by other simple analgesics, eg, paracetamol (Smith, 1971). The underlying pathogenetic mechanism is unknown. The sharp increase in airways obstruction soon after ingestion suggests an allergic reaction. Extensive studies, however, have failed to find an immunological mechanism (Giraldo, Blumenthal, and Spinks, 1969; Girard, Hildenbrandt, and Favre, 1969), and IgE levels have been within normal limits (Henderson, Swedlund et al., 1971). Asthmatics with aspirin idiosyncrasy are considered to form a subgroup of intrinsic asthma.

It has been suggested that the complement system may be activated directly by aspirin in sensitive subjects (Yurchak, Wicher, and Arbesman, 1970) and that this may lead to the elaboration of anaphylatoxins which in turn release histamine and other mediators of the allergic response by a mechanism independent of IgE.

Measurements of complement components in asthma have recently revealed high levels of $\mathrm{C} 4$ in the serum of allergic asthmatics and low levels in the serum of non-allergic asthmatics (Kay et al., 1974).

In the present study, serum IgE measurements were undertaken to confirm that, in general, normal levels occur in asthmatics with aspirin idiosyncrasy. Measurements of serum complement components were undertaken to determine if there was any alteration in the complement profile, especially $\mathrm{C4}$, in this condition. Absence of an altered profile would distinguish this subgroup of asthma from others in the intrinsic group.

\section{PATIENTS AND METHODS}

PATIENTS Sixteen patients with asthma and aspirin idiosyncrasy were investigated. The diagnosis of aspirin idiosyncrasy had been suggested by the history and was confirmed by oral challenge with paracetamol and small doses of soluble aspirin. The clinical features of those patients are outlined in the Table. Nasal speculum examination revealed the presence of polyps in all the patients. Skin testing by the prick-method revealed four patients with positive reactions to one or more common allergens.

Age- and sex-matched adults attending the general medical clinic were used as controls. None of these patients had allergic disease, asthma or other respiratory disorders. The age-range in asthmatics was 21 to 67 years (mean 46.6 years) and in the controls it was 25 to 67 years (mean 47.5 years). Sera were collected at outpatient clinics, randomly numbered, and stored at $-70^{\circ} \mathrm{C}$. Measurements of $\mathrm{IgE}$ and complement components were made by one of us (ABK) without knowledge of the origin of the samples. 
T A B L E

CLINICAL FEATURES OF PATIENTS WITH ASTHMA AND ASPIRIN IDIOSYNCRASY

\begin{tabular}{|c|c|c|c|c|c|c|c|}
\hline Patient & Age & Sex & \multicolumn{2}{|c|}{ Skin Tests } & $\begin{array}{l}\text { Nasal } \\
\text { Polypectomy } \\
\text { (No.) }\end{array}$ & $\begin{array}{c}\text { Asthma } \\
\text { (years) }\end{array}$ & $\begin{array}{l}\text { Steroid Therapy } \\
\text { (daily dose) }\end{array}$ \\
\hline
\end{tabular}

DP = Dermatophagoides pterynissinus (house-dust mite).

A $=$ aspergillus.

$\mathrm{G}=$ grass-pollen.

Pred $=$ prednisolon

METHODS The total haemolytic complement $\left(\mathrm{CH}_{50}\right)$ was measured by the method of Mayer (1961). Sheep cells were optimally sensitized by antisera prepared in the rabbit. Increasing dilutions of serum were added to constant volumes of sheep cells and the degree of haemolysis $(\mathrm{Y})$ was measured by spectrometry at OD 414 . The total haemolytic complement giving $50 \%$ haemolysis $\left(\mathrm{CH}_{50}\right)$ was calculated as $1-1 / \mathrm{r}$.

Levels of $\mathrm{C} 3$ and $\mathrm{C} 4$ were measured by radial immunodiffusion using monospecific antisera raised in the rabbit (Lachmann, Hobart, and Aston, 1973).

Levels of IgE were measured by solid phase radioimmunoassay using the Phadebas Kit (Pharmacia) in which the anti IgE was raised in the rabbit. The IgE of the standard sera in the kit was checked against WHO standard 68/341 and both had virtually identical values.

\section{RESULTS}

The complement profiles and $\operatorname{IgE}$ values for the groups with aspirin idiosyncrasy and for the control groups are outlined in the Figure.

The mean complement components for the two groups were as follows:

Asthmatics: $\quad \mathrm{CH}_{50}=132, \mathrm{C} 4=119, \mathrm{C} 3=136$

Controls: $\quad \mathrm{CH}_{50}=148, \mathrm{C} 4=125, \mathrm{C} 3=129$

(The values are expressed as a percentage of the normal pooled serum.)

There was no significant difference in the complement profiles between the two groups.
The IgE levels were mostly in the lower range in both groups. The mean IgE in the asthmatic. groups was $281 \mathrm{IU}$ per $\mathrm{ml}$ and in the controls it? was $150 \mathrm{IU}$ per $\mathrm{ml}$. The two asthmatic patients with raised IgE levels had positive skin tests.

\section{DISCUSSION}

Asthmatic patients with aspirin idiosyncrasy form a subgroup of chronic (intrinsic) asthma. Recently, chronic asthmatics have been shown to have lower levels of circulating $\mathrm{C} 4$ than episodic (extrinsic) patients. In the present study, how-O ever, there was no significant difference in the levels of complement components betweeno asthmatic patients with aspirin idiosyncrasy and controls. Apart from the two atopic patients theo finding of normal IgE values is in agreement with previous reports. Measurements of complemento components have not previously been recorded in this condition. The normal profile does not ex-을 clude direct activation of the complement system $\bar{N}$ by aspirin and, in this respect, measurements of ${ }^{\circ}$ complement levels during acute episodes provoked by aspirin would be helpful.

The absence of an altered complement profileo in asthmatics with aspirin idiosyncrasy would sup ro port the belief that patients with this syndrome form a subgroup quite separate from others in? the intrinsic asthma group.

Part of this work was supported by the Scottish Homed and Health Department. We are grateful to $\mathrm{Mr}$. Roger Dunmow for technical assistance. 


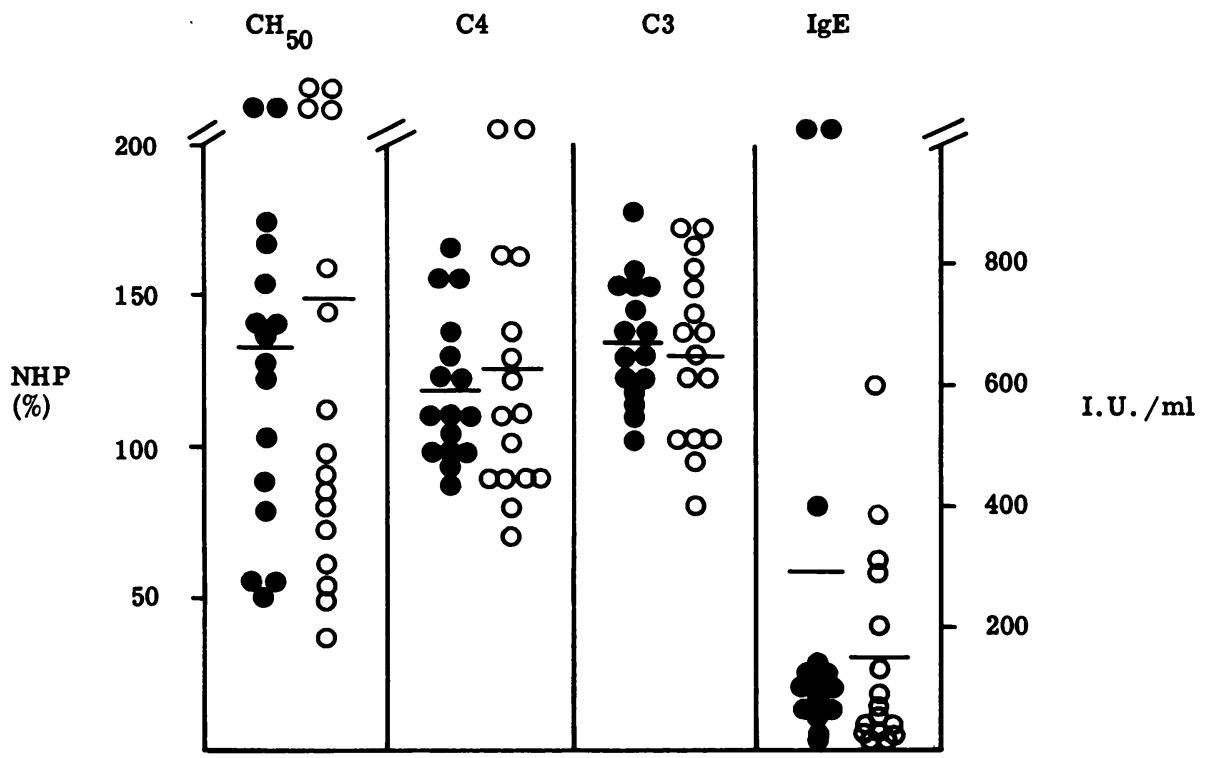

FIGURE Complement and IgE levels in patients with asthma and aspirin idiosyncrasy (O) and age- and sex-matched controls (O). The bars represent the mean values. There was no statistical difference between patients and controls as assessed by the Student $\mathrm{t}$ test. $N H P=$ normal human pool (serum).

\section{REFERENCES}

Giraldo, B., Blumenthal, M. N., and Spink, W. W. (1969). Aspirin intolerance and asthma: a clinical and immunological study. Annals of Internal Medicine, 71, 479.

Girard, J. P., Hildenbrandt, F., and Favre, H. (1969). Hypersensitivity to aspirin: clinical and immunological studies. Helvetia Medica Acta, 35, 86.

Henderson, L. L., Swedlund, H. A., Van Dellen, R. G., Marcoux, J. P., Carryer, H. M., Peters, G. A., and Gleich, G. J. (1971). Evaluation of IgE tests in an allergy practice. Journal of Allergy and Clinical Immunology, 48, 461.

Kay, A. B., Bacon, G. D., Mercer, B. A., Simpson, H., and Crofton, J. W. (1974). Complement components and IgE in bronchial asthma. Lancet, 2, 916.

Lachmann, P. J., Hobart, M. J., and Aston, W. P. (1973). Complement technology. In Handbook of
Experimental Immunology, edited by D. M. Weir, chapter 5. Blackwell, Oxford.

Mayer, M. M. (1961). In Experimental Immunochemistry, edited by E. A. Kabat and M. M. Mayer, 2nd edition, p. 133. Thomas, Springfield, Illinois.

Samter, M. and Beers, R. F., Jr. (1967). Concerning the nature of intolerance to aspirin. Journal of Allergy, 40, 281.

Smith, A. P. (1971). Response of aspirin-allergic patients to challenge by some analgesics in common use. British Medical Journal, 2, 494.

Yurchak, A. M., Wicher, K., and Arbesman, C. E. (1970). Immunologic studies on aspirin. Clinical studies with aspiryl-protein conjugates. Journal of Allergy, 46, 245.

Requests for reprints to: Dr. J. C. Delaney, Whiston Hospital, Prescot, Merseyside. 